DOI: 10.38136/jgon.941795

\title{
The utility of pulsatility index and diastolic notch presence in uterine artery doppler ultrasound between 18-24 weeks for preeclampsia prediction
}

\section{8-24 hafta uterin arter doppler ultrasonografisinde pulsatilite indeksinin ve diyastolik çentik varliğinin preeklampsi öngörüsündeki önemi}

\author{
Sule GONCU AYHAN \\ (1) Orcid ID:0000-0002-5770-7555 \\ Resul ARISOY \\ (1) Orcid ID:0000-0003-1359-1674 \\ Veli MIHMANLI 3 \\ (1) Orcid ID:0000-0001-8701-8462
}

\begin{abstract}
${ }^{1}$ MD, Ministry of Health Ankara City Hospital, Department of Obstetrics and Gynecology, Ankara, Turkey
${ }^{2}$ Ass. Prof, Uskudar University, Department of Obstetrics and Gynecology, Istanbul, Turkey.

${ }^{3}$ Prof, Ministry of Health Prof. Dr. Cemil Tascioglu City Hospital, Department of Obstetrics and Gynecology, Istanbul, Turkey.
\end{abstract}

\section{ÖZ}

Amaç: Íkinci trimester uterin arter pulsatilite indeksi (PI) değerinin ve diyastolik çentik varlığının primigravid, düşük riskli gebe hastalarda preeklampsi öngörüsündeki önemini saptamaktır.

Gerekçeler ve Yöntem: Primigravid, tekil, 18-24 haftası arasında olan 244 gebe hasta çalışmaya dahil edildi. Doppler ultrason ölçümleri transabdominal olarak yapıdı. Uterin arter Pi değeri ve diyastolik çentik varlığı not edildi. Daha önce normotansif olan bir gebede, 20. gebelik haftası ve sonrasında yeni başlayan hipertansiyon (> $140 / 90 \mathrm{mmHg}$ ) ve proteinüri (24 saatlik idrarda $300 \mathrm{mg}$ ve üzeri), proteinüri yokluğunda hipertansiyona eşlik eden sistemik bulguların bulunması preeklampsi olarak değerlendirildi. 32 gebelik haftası öncesi preeklampsi gelişmesi erken preeklampsi olarak tanımlandı.

Bulgular: Preeklampsi gözlenen 15 gebenin ortalama PI değeri $(1,51)$, preeklampsi gözlenmeyen gebelerinkinden $(0,89)$ anlamlı olarak yüksek bulundu $(p<0,001)$. Preeklampsi öngörüsü için duyarılığı ve özgüllüğü en yüksek olan eşik Pi değeri 1,13 olarak hesaplandı. Diyastolik çentik gözlenen gebelerde preeklampsi ve erken preeklampsi gelişme oranı, çentik negatif olan gebelere göre anlamlı olarak artmışıı $(p<0,001)$. Preeklampsi gözlenen 15 gebenin 13 'ünde iki taraflı, ikisinde ise tek taraflı çentik pozitifti.

Sonuç: Uterin arter Doppler değerlendirmesi, yüksek riskli gebelikleri belirlemek için kullanılabilecek non-invaziv ve basit bir araçtır. Özellikle anormal UA-PI değerlerine $(>1,13)$ eşlik eden bilateral diyastolik çentik saptanan gebelerde preeklampsi gelişme riski daha yüksektir. Yakın hasta izlemi, yüksek risk gruplarında hem maternal hem de fetal morbidite ve mortaliteyi azaltmaya yardımcı olabilir.

Anahtar kelimeler: Diyastolik çentik, Uterin arter doppleri, Preeklampsi, Pulsatilite indeksi

\section{ABSTRACT}

Aim: To determine the importance of second trimester uterine artery pulsatility index (PI) value and the presence of diastolic notch in the prediction of preeclampsia in primigravid, low-risk pregnant women.

Materials and Methods: Primigravid, singleton, 244 pregnant women between 1824 weeks of gestation included the study. Doppler ultrasound measurements were done transabdominally. Uterine artery PI value and the presence of diastolic notch were noted. Presence of new-onset hypertension $(>140 / 90 \mathrm{mmHg}$ ) and proteinuria (300 $\mathrm{mg}$ or more in 24-hour urine) or systemic findings accompanying hypertension in the absence of proteinuria in a pregnant woman who was normotensive before was considered preeclampsia. The development of preeclampsia before 32 weeks of gestation was defined as early preeclampsia.

Results: The mean PI value of the 15 pregnant women with preeclampsia $(1,51)$ was found to be significantly higher than that of the pregnant women without preeclampsia $(0,89)(p<0.001)$. The threshold PI value with the highest sensitivity and specificity for the prediction of preeclampsia was calculated as 1,13 . The preeclampsia and early preeclampsia rates in pregnant women with diastolic notch were significantly higher than in pregnant women with negative notch $(p<0.001)$. Bilateral notch was positive in 13 of 15 pregnant women with preeclampsia, and unilateral notch was positive in two.

Conclusion: Uterine artery Doppler is a non-invasive and simple tool to identify high-risk pregnancies and may improve patient-specific practice. Especially pregnant women with a bilateral uterine diastolic notch accompanying with abnormal UA-PI values $(>1,13)$ have higher risk to develop preeclampsia. Closer monitoring may help to reduce both maternal and fetal morbidity and mortality in high-risk groups.

Keywords: diastolic notch, uterine artery doppler, preeclampsia, pulsatility index 


\section{INTRODUCTION}

Preeclampsia $(\mathrm{PE})$ is a multisystemic disease characterized by the new onset of hypertension plus proteinuria and/or end-organ dysfunction after 20 weeks of gestation and a common risk factor for both perinatal and maternal morbidity, mortality worIdwide (1). Since the only effective treatment is delivery, prediction and intervention of PE become very important to improve maternal and perinatal outcomes.

Prophylactic use of aspirin in high-risk women presents reduce risk of preterm PE (2). Thus, the determination of high-risk group becomes crucial but, the complexity of pathogenesis make it difficult. Placenta-mediated pregnancy complication has been widely used recently in the literature and includes preeclampsia, placental abruption, intrauterine growth restriction, and late fetal loss (3). Abnormal placentation due to inadequate trophoblastic invasion is accused in these cases $(4,5)$. This process ended up with high resistance in uteroplacental circulation and reflected abnormal uterine artery (UA) Doppler patterns. Angiogenic modulators like vascular endothelial growth factor (VEGF), placental induced growth factor (PIGF), soluble endoglin (sEng), and soluble fms-like tyrosine kinase 1 (sFlt-1) were widely investigated for PE prediction but, blood and urine levels of these factors have not been proven to be clinically useful for this purpose (6). A meta-analysis reported that an increased pulsatility index (PI) with diastolic notching (DN) especially in the second trimester provides the best overall $\mathrm{PE}$ prediction in both low-risk and high-risk patients (6). Whether ultrasonographic screening does not recommend for the lowrisk population, finding a cut-off value for UA PI and the effect of $D N$ presence on $P E$ development risk would allow early intervention for possible PE complications in this group.

This study aims to determine the utility of second trimester UA $\mathrm{PI}$ values and DN presences in primigravid, low-risk pregnant women for PE prediction.

\section{MATERIALS AND METHODS}

This is a prospective cohort study conducted in the Turkish Ministry of Health Okmeydanı Research Hospital, Obstetrics and Gynecology Clinics with primigravid pregnant women. Primigravid, singleton, healthy, between 18-24 gestational weeks pregnant women selected as a study population. Women known to have multifetal pregnancies, fetal structural anomalies, maternal systemic diseases, maternal uterine anomalies were excluded. Written informed consent was obtained from all participants. The applied protocol was approved by the Medical Research Ethics Department.

The last menstrual period or first-trimester crown-rump length was used to determine gestational age. Doppler measurements were performed between 18 and 24 weeks 88 f gestation by the same obstetrician using software of the Toshiba Xario Ultrasound (USG) machine, transabdominal PVU-375BT6C1 convex probe (1.9-6 Mhz). All USG examinations were performed by the same obstetricians (SGA, RA). Patients were examined in a semi-Fowler position to avoid orthostatic hypotension. UA was identified at the level where they cross the external iliac artery bilaterally. Pulsed wave Doppler is then applied with an insonation angle $<30^{\circ}$ and a sampling volume of $2 \mathrm{~mm}$. At least three uniform waves were analyzed. $\mathrm{PI}$ is then obtained using the average PI measurement of both right and left arteries and DN was noted if it was found.

Diagnostic criteria for pre-eclampsia were new-onset persistently high systolic $(140 \mathrm{~mm} \mathrm{Hg}$ ) or diastolic $(90 \mathrm{~mm} \mathrm{Hg})$ blood pressure and proteinuria $(0.3 \mathrm{~g}$ of protein in 24-hour urine collection) or hypertension and end-organ dysfunction after 20 weeks of gestation. Early PE was defined as the development of $P E$ before 32 weeks gestation.

SPSS 17 was used for statistical analysis. The Shapiro- Wilk test, Kolmogorov-Smirnov test were used to determine the distribution of normality. The continuous variables were presented as mean and standard deviations. Groups were compared with The Student's t-test and Mann-Whitney U test. A type-1 error below 0.05 was considered statistically significant. ROC curve was used to evaluate the UA-PI cut-off value for PE prediction.

\section{RESULTS}

Of the 244 primigravid pregnant women, $15(6,1 \%)$ developed PE. When Preeclampsia positive (PEP) group and the preeclampsia negative (PEN) group were compared, there was no difference in demographic data. PEP group mean UA-PI value was significantly higher $(p<0,01)$ when mean time of the delivery week $(p<0,01)$ and fetal birth weight $(p<0,01)$ were significantly lower than PEN group. Table 1 shows the basic characteristics of patients with PE $(n=15)$ and without PE $(n$ $=229$ ). 
Table 1. Basic Characteristics of Patients with and without Preeclampsia $(n=244, \%)$

\begin{tabular}{|l|c|c|c|}
\hline Basic Characteristics & $\begin{array}{c}\text { Preeclampsia } \\
\text { Negative (n=229, } \\
\% 93,9)\end{array}$ & $\begin{array}{c}\text { Preeclampsia } \\
\text { Positive (n=15, } \\
\% 6,1)\end{array}$ & $P$ \\
& $\begin{array}{c}\text { Mean +/-SD } \\
\text { Mean +/-SD }\end{array}$ & \\
\hline Age & $22,99 \pm 3,58$ & $22,23 \pm 3,89$ & 0,290 \\
\hline Gestational Week (USG) & $21,74 \pm 1,33$ & $21,07 \pm 1,10$ & 0,055 \\
\hline Pulsatility Index & $0,890 \pm 0,20$ & $1,510 \pm 0,42$ & $<0,001^{*}$ \\
\hline Birth Week & & & \\
\hline Fetal Birth Weight (gr) & $3221 \pm 547$ & $1952 \pm 713$ & $<0,001^{*}$ \\
\hline${ }^{p} p<0,05$ & & & \\
\hline
\end{tabular}

DN was negative (NN) in $163(66,8 \%)$ pregnant women, and found positive (NP) in $81(33,2 \%)$ pregnant women (Table 2). Table 3 provides a relation between DN and early PE. Unilateral notch positivity was $48(19,7 \%)$, while 33 of the patients $(13,5 \%)$ had bilateral notch positivity. Bilateral DN and early PE relation was given in Table 4, and Table 5 shows bilateral DN and $P E$ relation.

Table 2. Diastolic Notch and Preeclampsia Relation $(n=244, \%)$

\begin{tabular}{|l|l|l|l|}
\hline & PEN & PEP & \\
\hline NN & $163(\% 66,8)$ & 0 & \\
\hline NP & $66(\% 27,1)$ & $15(\% 6,1)$ & $\mathrm{p}<0,0001$ \\
\hline $\begin{array}{l}\text { NN: Notch Negative, NP: Notch Positive, } \\
\text { PEN: Preeclampsia Negative, PEP: Preeclampsia Positive }\end{array}$ \\
\hline
\end{tabular}

Table 3. Diastolic Notch and Early Preeclampsia Relation $(n=244, \%)$

\begin{tabular}{|l|l|l|l|}
\hline & EPEN & \multicolumn{2}{|l|}{ EPEP } \\
\hline $\mathrm{NN}$ & $163(\% 66,8)$ & 0 & $\mathrm{p}=0,0037$ \\
\hline $\mathrm{NP}$ & $76(\% 31,1)$ & $5(\% 2,1)$ & \\
\hline \multicolumn{3}{|l|}{$\begin{array}{l}\text { NN: Notch Negative, NP: Notch Positive, } \\
\text { EPEN: Early Preeclampsia Negative EPEP: Early Preeclampsia Positive }\end{array}$} \\
\hline
\end{tabular}

Table 4. Bilateral Diastolic Notch and Early Preeclampsia Relation $(n=244, \%)$

\begin{tabular}{|l|l|l|c|}
\hline & EPEN & EPEP & \\
\hline NN + UNP & $211(\% 86,5)$ & 0 & \\
\cline { 1 - 3 } BNP & $28(\% 11,4)$ & $5(\% 2,1)$ & $\mathrm{p}<0,0001$ \\
\hline $\begin{array}{l}\text { NN: Notch Negative, UNP: Unilateral Notch Positive, BNP: Bilateral Notch Positive, } \\
\text { EPEN: Early Preeclampsia Negative, EPEP: Early Preeclampsia Positive }\end{array}$ \\
\hline
\end{tabular}

Table 5. Bilateral Diastolic Notch and Preeclampsia Relation $(n=244, \%)$

\begin{tabular}{|l|l|l|l|}
\hline & PEN & \multicolumn{2}{|l|}{ PEP } \\
\hline NN + UNP & $209(\% 85,7)$ & $2(\% 0,8)$ & $\mathrm{p}<0,0001$ \\
\hline BNP & $20(\% 8,2)$ & $13(\% 5,3)$ & \\
\hline $\begin{array}{l}\text { NN: Notch Negative, UNP: Unilateral Notch Positive, BNP: Bilateral } \\
\text { Notch Positive, PEN: Preeclampsia Negative, PEP: Preeclampsia } \\
\text { Positive }\end{array}$ \\
\hline
\end{tabular}

Figure 1 shows Roc analyses to establish cut of UA-PI for PE prediction and 1,13 found most sensitive (93\%) and specific $(88 \%)$ value for this purpose.

Figure 1. ROC Curve

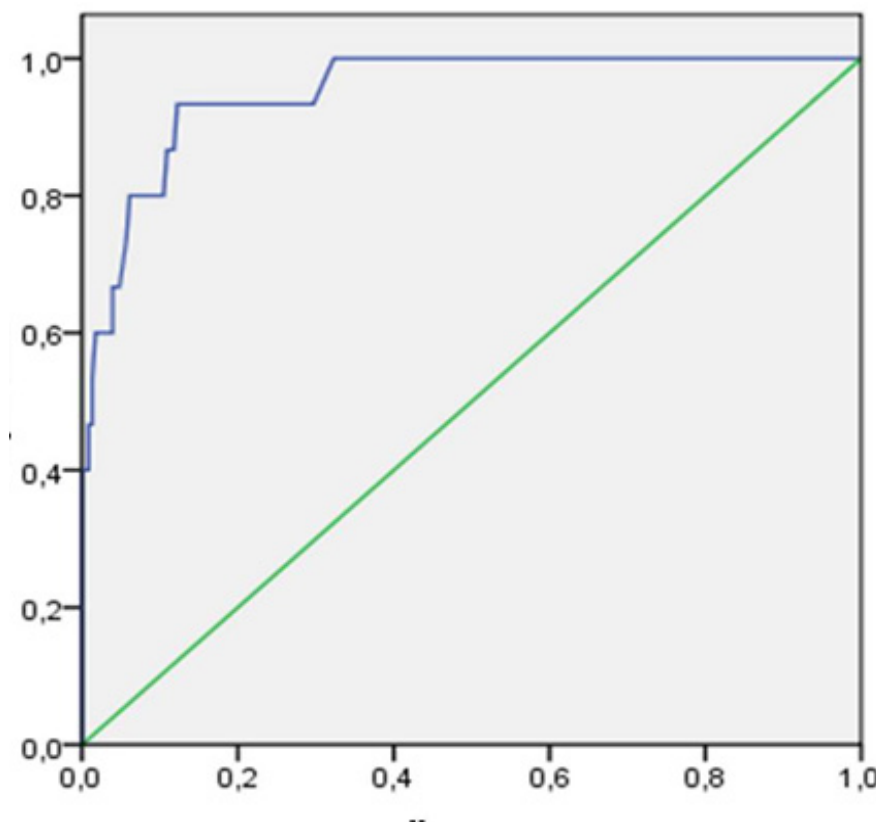

AUC: 0,952, most sensitive (93\%) and specific (88\%) value of UA-PI for PE prediction found 1,13

\section{DISCUSSION}

In the present study, we found a 1,13 value as a cut-off for UA-PI to PE prediction between 18-26 GW in primigravid, lowrisk pregnant women. In addition, the presence of bilateral DN increases the risk of $P E$ in this group. 
UA Doppler evaluation has been used to determine advanced pregnancy outcomes for many years (7-10). Due to physiological changes in spiral arteries between 6-24 weeks, the Doppler flow velocity shows high capacitance and low resistance pattern (11-13). Therefore, inadequate placentation causes high impedance in UA and results abnormal UA Doppler parameters. Several studies investigated the value of uterine artery Doppler indices in predicting the development of adverse pregnancy outcomes and results varied widely. Schwarze et al. evaluated the role of uterine artery Doppler ultrasound in predicting adverse outcomes in pregnancy in low-risk women at 23-26 gestational weeks and, found low sensitivity for predicting $\mathrm{PE}$, using resistance index (RI) cutoff of 0.58 or 0.7 or any notch in one or both uterine arteries. On the other hand, Bhattacharyya et al. (14) and Espinoza et al. (15) reported that UA Doppler abnormalities are an independent predictor of the development of PE. In the present study, PEP group mean UA$P I$ value was significantly higher $(p<0,01)$ when the mean time of the delivery week $(p<0,01)$ and fetal birth weight $(p<0,01)$ were significantly lower than PEN group. This is consistent with high resistance blood flow in UA and adverse outcomes of insufficient placentation in PE.

Roc analyses determined, 1,13 UA-PI as a most sensitive (93 $\%$ ) and specific (88\%) cut-of value for PE prediction (figure 1) in the present study. AUC calculated 0,952 $\pm 0,022(p<0,001)$.

UA notch pathophysiology has not been clarified completely and increased compliance of the arterial wall or UA endothelial cell dysfunction blamed previous studies $(16,17)$. Ratiu et.al published a study that points, pregnant women with bilateral uterine notching had higher maternal and fetal morbidity compared to women presenting only unilateral uterine notching in the second trimester (18). In the present study, we found similar results. Notch positivity increased PE and early PE risk significantly when compared to notch negativity $(p<0,001)$.

Of to 15 PEP group, 13 had bilateral uterine notching and 2 had unilateral uterine notching. Additionally, the mean PI value found 1,51 in the bilateral uterine notching group when it was 1,06 and 0,84 in unilateral uterine notching and notch negative group respectively. However, 48 of unilateral uterine notching group only 2 developed PE. Mean PI was less than 1,13 in this group which may be the explanation of this result.

The utility of UA Doppler analyses for PE prediction was demonstrated in a systematic review of 74 studies including almost 80,000 women (7). Both low-risk and high-risk pregnant women for PE and 15 UA Doppler indices were involved in the study and reported that UA Doppler evaluation was more accurate when performed in the second trimester than in the first trimester. Also, UA-PI was the best predictive tool for PE prediction when accompanied with UA notching. In the present study second trimester, pregnant women were examined for $P E$ prediction using UA-PI and notching together consistent with this systematic review.

The main strength of this study is a prospective design with adequate follow-up until delivery and, a homogenous group about demographic features. The small sample size was the main limitation of the present study.

In conclusion, whether UA doppler examinations do not recommend for routine PE screening, it is a non-invasive and simple tool for identifying high-risk pregnancies and may improve patient-specific practice. Prophylactic use of aspirin, closer monitoring, and determining the best time for intervention to high-risk groups enables to reduce both maternal and fetal morbidity and mortality $(2,8,18-21)$. Especially pregnant women with a bilateral uterine notch plus abnormal UA-PI values resulted a higher prevalence to develop these severe adverse outcomes $(18,21)$.

Acknowledgment: Special thanks to all healthcare staff who work in obstetrics and gynecology clinic.

Funding: No funding was used for this study.

Conflict of interest statement: All authors state that they have no conflict of interest in this study.

\section{REFERENCES}

1. Duley L. The global impact of pre-eclampsia and eclampsia. Semin Perinatol 2009;33(03):130-137.

2. Rolnik DL, Wright D, Poon LC, O'Gorman N, Syngelaki A, de Paco Matallana $C$, et al. Aspirin versus Placebo in Pregnancies at High Risk for Preterm Preeclampsia. N Engl J Med. 2017;377(7):613-22.

3. Skeith L, Blondon M, Ní Áinle F. Understanding and Preventing Placenta-Mediated Pregnancy Complications. Hamostaseologie. 2020 Aug;40(3):356-363.

4. Wallace AE,Whitley GS, Thilaganathan B, Cartwright JE. Decidual natural killer cell receptor expression is altered in pregnancies with impaired vascular remodeling and a higher risk of preeclampsia. J Leukoc Biol 2015;97(01):79-86.

5. Brosens IA, Robertson WB, Dixon HG. The role of the 
spiral arteries in the pathogenesis of preeclampsia. Obstet Gynecol Annu 1972;1:177-191

6. Kleinrouweler CE, Wiegerinck MM, Ris-Stalpers C, Bossuyt PM, van der Post JA, von Dadelszen P et.al. Accuracy of circulating placental growth factor, vascular endothelial growth factor, soluble fms-like tyrosine kinase 1 and soluble endoglin in the prediction of pre-eclampsia: a systematic review and meta-analysis. BJOG. 2012;119(7):778.

7. Cnossen JS, Morris RK, ter Riet G, Mol BW, van der Post JA, Coomarasamy A et. al Use of uterine artery Doppler ultrasonography to predict pre-eclampsia and intrauterine growth restriction: a systematic review and bivariable meta-analysis. CMAJ. 2008 Mar 11;178(6):701-11.

8. Gallo DM, Poon LC, Akolekar R, Syngelaki A, Nicolaides KH. Prediction of preeclampsia by uterine artery Doppler at 20-24 weeks' gestation. Fetal Diagn Ther. 2013;34(4):241-7. doi:

9. Adefisan AS, Akintayo AA, Awoleke JO, Awolowo AT, Aduloju OP. Role of second-trimester uterine artery Doppler indices in the prediction of adverse pregnancy outcomes in a lowrisk population. Int J Gynaecol Obstet. 2020 Nov;151(2):209213.

10. Papageorghiou AT, Yu CK, Cicero S, Bower S, Nicolaides $\mathrm{KH}$. Second-trimester uterine artery Doppler screening in unselected populations: a review. J Matern Fetal Neonatal Med. 2002 Aug;12(2):78-88.

11. Oloyede OA, Iketubosin F. Uterine artery Doppler study in second trimester of pregnancy. Pan African Med J 2013;15(1).

12. Afrakhteh $M$, Moeini $A$, Taheri MS, Haghighatkhah $H R$, Fakhri M, Masoom N. Uterine Doppler velocimetry of the uterine arteries in the second and third trimesters for the prediction of gestational outcome. Rev Bras Ginecol Obstet 2014;36(1):35-39.

13. Schwarze A, Nelles I, Krapp M, Friedrich M, Schmidt $\mathrm{W}$, Diedrich $\mathrm{K}$ et. al. Doppler ultrasound of the uterine artery in the prediction of severe complications during low-risk pregnancies. Arch Gynecol Obstet. 2005 Jan;271(1):46-52.
14. Bhattacharyya SK, Kundu S, Kabiraj SP. Prediction of preeclampsia by midtrimester uterine artery Doppler velocimetry in high-risk and low-risk women. J Obstet Gynecol India 2012;62(3):297-300.

15. Espinoza J, Romero R, Nien JK, Gomez R, Kusanovic JP, Gonçalves LF et. al Identification of patients at risk for early onset and/or severe preeclampsia with the use of uterine artery Doppler velocimetry and placental growth factor. Am J Obstet Gynecol. 2007 Apr;196(4):326.e1-13.

16. Espinoza J, Kusanovic JP, Bahado-Singh R, Gervasi MT, Romero R, Lee W, et. al. Should bilateral uterine artery notching be used in the risk assessment for preeclampsia, small-for-gestational-age, and gestational hypertension. J Ultrasound Med 2010; 29: 1103-1115,

17. Brodszki J, Länne T, Stale H akan, Batra S and Maršál $\mathrm{K}$ : Altered vascular function in healthy normotensive pregnant women with bilateral uterine artery notches. BJOG 2002; 109: 546-552.

18. Ratiu D, Hide-Moser K, Morgenstern B, Gottschalk I, Eichler C, Ludwig S. et. al. Doppler Indices and Notching Assessment of Uterine Artery Between the 19th and 22nd Week of Pregnancy in the Prediction of Pregnancy Outcome. In Vivo. 2019 Nov-Dec;33(6):2199-2204.

19. Lesmes C, Gallo DM, Saiid Y, Poon LC and Nicolaides $\mathrm{KH}$ : Prediction of small-for-gestational-age neonates: screening by uterine artery Doppler and mean arterial pressure at 19-24 weeks. Ultrasound Obstet Gynecol 2015; 46: 332-340.

20. Poon LC, Volpe N, Muto B, Yu CK, Syngelaki A, Nicolaides $\mathrm{KH}$. Second-trimester uterine artery Doppler in the prediction of stillbirths. Fetal Diagn Ther. 2013;33(1):28-35.

21. Giordano R, Cacciatore A, Romano M, La Rosa B, Fonti I, Vigna R. Uterine artery Doppler flow studies in obstetric practice. J Prenat Med 2010;4(4):59. 